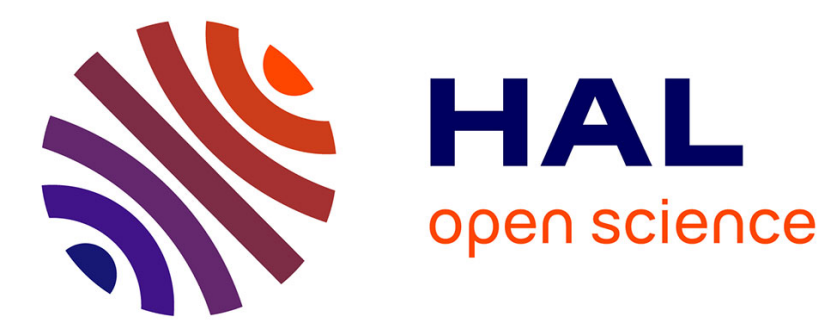

\title{
Spatial accessibility to amenities in fractal and non fractal urban patterns
}

Cécile Tannier, Gilles Vuidel, Hélène Houot, Pierre Frankhauser

\section{To cite this version:}

Cécile Tannier, Gilles Vuidel, Hélène Houot, Pierre Frankhauser. Spatial accessibility to amenities in fractal and non fractal urban patterns. Environment and Planning B: Planning and Design, 2012, 39 (5), pp.801-819. 10.1068/b37132 . hal-00804263

\section{HAL Id: hal-00804263 https://hal.science/hal-00804263}

Submitted on 14 Jun 2021

HAL is a multi-disciplinary open access archive for the deposit and dissemination of scientific research documents, whether they are published or not. The documents may come from teaching and research institutions in France or abroad, or from public or private research centers.
L'archive ouverte pluridisciplinaire HAL, est destinée au dépôt et à la diffusion de documents scientifiques de niveau recherche, publiés ou non, émanant des établissements d'enseignement et de recherche français ou étrangers, des laboratoires publics ou privés.

\section{(ㄷ)(1) $\$$}

Distributed under a Creative Commons Attribution - NonCommercial| 4.0 International 
TANNIER C., VUIDEL G., HOUOT H., FRANKHAUSER P. (2012), Spatial accessibility to amenities in fractal and non fractal urban patterns, Environment and Planning B: Planning and Design, vol. 39, n5, pp. 801-819.

\section{EPB 137-132: Spatial accessibility to amenities in fractal and non fractal urban patterns}

Cécile TANNIER* (cecile.tannier@univ-fcomte.fr) - corresponding author

Gilles VUIDEL*(gilles@vuidel.org)

Hélène HOUOT* (helene.houot@univ-fcomte.fr)

Pierre FRANKHAUSER* (pierre.frankhauser@univ-fcomte.fr)

* ThéMA, CNRS - University of Franche-Comté

32 rue Mégevand

F-25 030 Besançon Cedex, France

Tel: +33 381665481

Fax: +33 381665355 


\title{
Spatial accessibility to amenities in fractal and non fractal
}

\section{urban patterns}

\begin{abstract}
One of the challenges of urban planning and design is to come up with an optimal urban form that meets all of the environmental, social and economic expectations of sustainable urban development. In this perspective, some scholars have taken an interest in fractal urban forms. The objective of this paper is to evaluate the benefit of a fractal urban form in terms of spatial accessibility to local urban (shops and services) and rural (open spaces) amenities. To do this, we propose a multi-scale fractal simulation system named MUP-City for simulating various residential development scenarios based on an existing urban pattern. Using MUP-City over a single study area, we generate 50 fractal and non fractal urbanization scenarios and then compare them in terms of spatial accessibility to local amenities. Compared with non fractal urbanization scenarios, fractal scenarios involve travelling shorter distances to reach various types of open space, but greater distances to visit the various types of shops and services. Access to shops and services in fractal scenarios can be improved by altering the location of shops and services, whereas access to open spaces in non fractal scenarios cannot be improved without changing the built form of reference.
\end{abstract}

Keywords: urban form, fractal simulation, scenarios, accessibility, amenities

\section{Introduction}

Urban sprawl is a response to social demand for home ownership in quiet and green residential settings. Its adverse effects on the environment are no longer in doubt due in particular to the increased number and length of trips by car. When opening up new areas for urbanization, the 
challenge is to promote easy access to amenities (especially by walking and cycling) while taking into account other environmental considerations. However, the relationship between urban form and travelling behaviour is still not clearly established. Academic research into the connections between either compact, polycentric or ‘New Urbanism’ urban forms and travel behaviour is inconclusive. Results obtained differ depending on the methodology used, data limitations and spatio-temporal settings (Cervero and Murakami, 2010; Conway, 2009; Schwanen et al, 2001). To escape the constraints of case studies, some scholars have developed simulation models for forecasting the impact of travel behaviour on future urbanization concepts. These studies have failed to prove any one urbanization model is superior to any other. However, they have confirmed the influence of the land use pattern on travel behaviour (Geurs and van Wee, 2006). In this paper, we endeavour to provide new insights into this question by assessing whether or not a multi-scale (fractal) urban form is better than a single-scale (Euclidean) urban form considering spatial accessibility to various amenities.

\section{Literature review}

In urban planning and design, one common recommendation is to densify and urbanize vacant areas within the built pattern. The compact city model is usually rolled out because it allows easy access to urban amenities (e.g. Dantzig and Saaty, 1973; Newman and Kenworthy, 1989) but its limitations have been pointed out, especially road congestion, reduced access to green and natural areas, higher housing prices, and reduced living space (Breheny, 1997; Burton, 2000). The New Urbanism model has been developed as an alternative, primarily in the United States. It combines high building densities, mixed uses, grid street patterns, narrow streets, and short setbacks (Calthorpe, 1993). Another alternative urban model has also come to the fore combining reasonable densification, as in the 'wisely compact city' (Camagni et al, 2002), and a polycentric urban organization. The fractal city model (Frankhauser, 2004) has been put forward in accordance with these models. 
Following pioneering research supporting the assumption that cities are fractal (Batty and Longley, 1986; Frankhauser, 1988; Mandelbrot, 1982; White and Engelen, 1993), a string of publications has shown that urban growth engenders a fractal spatial organization (Batty and Xie, 1996; Benguigui et al, 2000; Shen, 2002; Thomas et al, 2008). Some contributions have explored the fractal aspects of area-perimeter relations and the fractal boundary of built forms (Arlinghaus and Nystuen, 1990; Longley and Batty, 1989). Yet others have discussed the scaling relationship between the number of built clusters and their size (Benguigui et al, 2006; Benguigui and Czamanski, 2004; White and Engelen, 1993). However, despite the number of scientific contributions, fractal models for urban planning have not been widely explored, and even less applied, in Europe and in the rest of the world. Applications have especially underscored the aesthetic and landscape quality of fractal urban forms (Stamps, 2002). Other works have compared accessibility to urban and rural amenities in both fractal (teragon and Sierpinski carpet) and non fractal (square city) theoretical urban patterns. Frankhauser (2000) has shown that the teragon provides better access to the urban boundary while allowing almost equivalent access to the main centre, and without occupying more land area than the square city does. Cavailhès et al (2004), and Frankhauser and Genre-Grandpierre (1998) have shown that, in terms of distance to urban and rural amenities, a city in the form of a Sierpinski carpet is more suitable than a compact city for people who frequently visit small and medium-sized centres, but not so often the main centre, and who want to be close to open spaces.

In operative terms, numerous pathways have been explored to determine where to open up new areas for urbanization. Some decision support tools can be used to identify potentially urbanizable sites from suitability functions and/or utility functions (Klosterman, 1999; Malczewski, 2004). Various techniques may then be used to select appropriate sites: multi-criteria analysis techniques or land-use allocation models (Janssen et al, 2008; Klosterman, 1999; Ligmann-Zielinska et al, 2008). Artificial intelligence models have also opened up the way for alternative approaches (Li and Liu; 
Saarlos et al, 2005). Some models cover a range of spatial objectives, in the form of a degree of compactness, of size and number of built clusters, or of housing density per hectare (Janssen et al, 2008; Li and Liu, 2008; Ligmann-Zielinska et al, 2008). In this way the compact city model may be translated implicitly by rules about densification or compactness. However, no SDSS or PSS is designed to generate a well-defined urban form, whether compact, polycentric or fractal.

\section{Content of the paper}

Is it possible to create a SDSS or a PSS that generates fractal urban forms while ensuring good local access to a range of amenities? Does the fractal city model provide a worthwhile alternative to the classic urban models of the compact or 'wisely compact' city in terms of access to amenities? To answer these two questions, we have created a multi-scale fractal simulation model named MUPCity. MUP-City takes an existing urban pattern and simulates various scenarios of residential development. Multi-scale modelling associated with a fractal urbanization rule determines the built patterns the city might take on. Additional constraints in terms of access to various amenities are used to modulate the built patterns proposed. By using MUP-City to generate fractal and non fractal urbanization scenarios, our aim is to assess the benefit of fractal urban patterns in terms of local access to a range of amenities. We measure spatial accessibility, but we do not go so far as to measure behavioural accessibility (Neutens et al, 2010) or to make accessibility benefit measurements (Geurs et al, 2010). 


\section{MUP-City: methodological description}

MUP-City is a computer application for identifying places where urbanization would be possible in accordance with a principle of fractal urbanization (Tannier et al, 2010). Four additional rules introduce constraints on access to shops and services, to open spaces and a constraint on proximity to the existing road network. The current version 0.7 of MUP-City applies to suburban areas of French cities of 100,000 to $1,000,000$ inhabitants. Only access to local amenities is considered: local access to shops and services used daily and weekly; direct proximity to built and non built areas. Access to city centre amenities is considered equivalent for all the inhabitants of the same suburban sector. Access is defined here in spatial terms alone: distance is not associated with potential frequentation, which supposedly varies with the number and type of individuals concerned.

\subsection{Multi-scale spatial modelling}

The study area is covered by a regular square grid. Each grid square contains a fixed number of cells. The number of cells per grid square is determined by a reduction factor $r$. When $r$ is 3 , the grid square contains nine cells. Multi-scale modelling consists in reducing the size of the grid square from one level of analysis to the next (Figure 1). Initially, the grid square size is $i_{1}$. At the next level of analysis, each grid square of size $i_{1}$ is subdivided into grid squares of size $i_{2}$, corresponding to the cells of level $i_{1}$.

$$
i_{2}=(1 / r) i_{1}
$$

This procedure of decomposing the grid squares into cells is reiterated until the cell size is close to that of the buildings. 
Figure 1. Sample application of the fractal rule of urbanization with $N_{\max }$ equal to 5 based on multi-scale spatial modelling
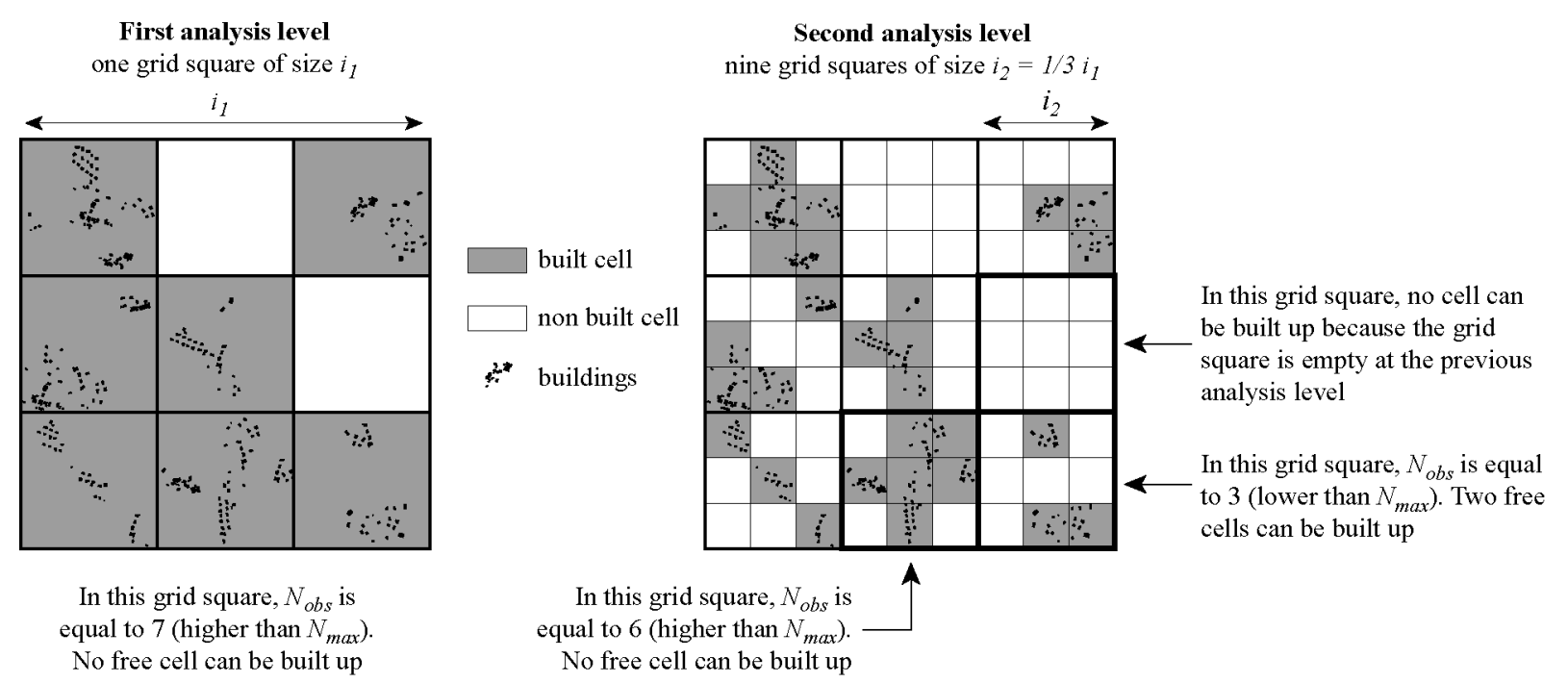

We obtain the built density by dividing the number of built cells by the total area of the initial square. This density changes as we move from one step of the decomposition $i$ to the next $i+1$, because new vacant cells appear in each of the built grid squares and the cell size becomes smaller. So from one step in the decomposition to the next, the built density is reduced by a factor corresponding to the proportion of the built area in each grid square, with respect to a given step $i$. In the case of a fractal built form, the reduction in density observed at decomposition step $i, \rho_{i}$, is related to that of the next step $\rho_{i+1}$ by the relation:

$$
\frac{\rho_{i+1}}{\rho_{i}}=\left(\frac{N^{i}}{r^{2 \mathrm{i}}}\right)=(r)^{(-2-\mathrm{D})}
$$

where $D$ is the built fractal dimension, $N$ the number of built elements at each level of analysis and $r$ the reduction factor from one level of analysis to the next. This relation is reminiscent of another relation between the decrease of density from centre to periphery and the radial fractal dimension shown by Batty and Kim (1992), Chen (2009), and Thomas et al. (2007).

\subsection{Fractal rule of urbanization}


We can calculate the self-similarity dimension $\left(D_{s}\right)$ of a built pattern across a series of levels of analysis from the relation:

$$
D_{s}=-\frac{\log N}{\log 1 / r}
$$

The self-similarity dimension (Ds) is equivalent to Mandelbrot's fractal dimension (D). In MUPCity, the choice of a fractal rule of urbanization corresponds to the choice of a fractal dimension for the future built pattern. This choice is reflected by the definition of a maximum number $N_{\max }$ of cells that can be built per grid square and by the choice of the reduction factor $r$. The fractal dimension approximated using this method is the box dimension (Gouyet, 1992).

Using MUP-City 0.7, we work with a constant $r$ of 3. A variable $N_{o b s}$ describes the number of cells currently urbanized in each grid square (Figure 1). If a grid square of size $i_{1}$ is not built, building is prohibited in the cells of size $i_{2}$ belonging to that grid square. In this, MUP-City operates strictly according to a principle of fractal urbanization, guided by the nesting and conservation of vacant areas from a global scale to a local scale. The multi-scale decomposition allows the addition of a spatial component to the fractal rule defined via the parameters $N_{\max }$ and $r$.

Further to the application of the fractal rule of urbanization, we know the number of cells in each grid square that can potentially be urbanized. Additional rules of accessibility are then used to select which cells to urbanize among the potentially urbanizable ones.

\subsection{Four additional rules of accessibility}

These four rules introduce constraints about access to shops and services, open spaces and about proximity to the existing road network (Table 1). Each rule is described by means of either one or two variables, formalized as fuzzy membership functions (Oh, 2002; Zadeh, 1965). The combining 
of variables in a rule involves aggregation operators that are also derived from fuzzy set theory (Yager, 1978; Zimmermann, 1987; Zimmermann and Zysno, 1983). Fuzzy set theory offers a range of mathematical tools for manipulating imprecise knowledge. In this paper, it is especially interesting to formalize compensation phenomena between variables with varying compensation degrees according to both the absolute and relative values of variables considered.

Table 1. Accessibility rules for evaluating which cells to urbanize

\begin{tabular}{|l|l|l|l|}
\hline Rule & Objectives & Variables \\
\hline 1. & $\begin{array}{l}\text { Ensure easy access to open } \\
\text { spaces and that they remain } \\
\text { interconnected }\end{array}$ & $\begin{array}{l}\text { The target cell must be adjacent to a built cell. } \\
\text { Urbanizing the target cell must not cut off } \\
\text { access to the open space from the surrounding } \\
\text { urbanized cells. }\end{array}$ & $\begin{array}{l}\text { Number of non built cells around each built } \\
\text { cell directly adjacent to the target cell (in a } \\
\text { Moore neighbourhood) }\end{array}$ \\
\hline 2. & $\begin{array}{l}\text { Ensure easy access to shopping } \\
\text { and service centres visited daily }\end{array}$ & $\begin{array}{l}\text { The target cell must be close enough to the } \\
\text { closest shopping and service centres visited } \\
\text { daily }\end{array}$ & $\begin{array}{l}\text { Distance between the target cell and the } \\
\text { shopping and service centres visited daily } \\
\text { Number and diversity of businesses in each } \\
\text { centre }\end{array}$ \\
\hline 3. & $\begin{array}{l}\text { Ensure easy access to shopping } \\
\text { and service centres visited } \\
\text { weekly }\end{array}$ & $\begin{array}{l}\text { The target cell must be close enough to the } \\
\text { closest shopping and service centres visited } \\
\text { weekly }\end{array}$ & $\begin{array}{l}\text { Distance between the target cell and the } \\
\text { shopping and service centres visited weekly } \\
\text { Number and diversity of businesses in each } \\
\text { centre }\end{array}$ \\
\hline 4. & $\begin{array}{l}\text { Proximity of the existing road } \\
\text { network }\end{array}$ & $\begin{array}{l}\text { The target cell must be crossed by or close to } \\
\text { a road }\end{array}$ & Distance to existing road \\
\hline
\end{tabular}

Each cell is therefore characterized by four evaluation values between 0 and 1 , one for each of the rules, with value 1 corresponding to the maximum evaluation. The four values are then aggregated by an arithmetic mean giving an overall evaluation for each cell of the benefit from its urbanization. Ultimately, the system selects the cells it would be most beneficial to urbanize in each grid square. This selection is made dynamically: in a given grid square, the cells are evaluated; the cell with the best evaluation is selected; the evaluations are re-calculated; a second cell with the best evaluation is selected, and so on. The operation is re-iterated in this way, for each grid square, until no further cells can be selected. In any grid square, when there is a tie between the cells evaluated, the choice of one or the other is made randomly. 


\section{Rule 1}

This rule must allow all residents of a suburban sector direct access to open spaces while avoiding the fragmentation of built and non built areas. Currently, open spaces are classified as non built spaces, which is a major simplification of the real-world situation and will need to be refined subsequently. For it to be worth urbanizing with respect to rule 1, a non built cell must have:

- at least one other non built cell in its immediate vicinity (neighbourhood R1), ensuring direct proximity of the cell to non built areas;

- non built cells adjacent to the built cells belonging to its immediate neighbourhood (neighbourhood R2), so as to maintain direct proximity to non built spaces for cells that are already built;

- the greatest possible number of built cells around the target cell (neighbourhood R1) while meeting the two conditions set out above.

The formalization of the rule is deduced from analysing all possible spatial configurations of $5 \times 5$ cells. The central cell is the target cell; it may have from 0 to 8 built cells around it (R1); all the 16 other cells are non built (R2). In this theoretical arrangement, one cell may have at most 34 non built cells neighbouring the built cells that are directly adjacent to it (see Figure 2). This number is reached when 6 built cells are adjacent to the target cell.

Figure 2. An example of spatial configuration of $3 \times 3$ built or non built cells surrounded by 16 non built cells
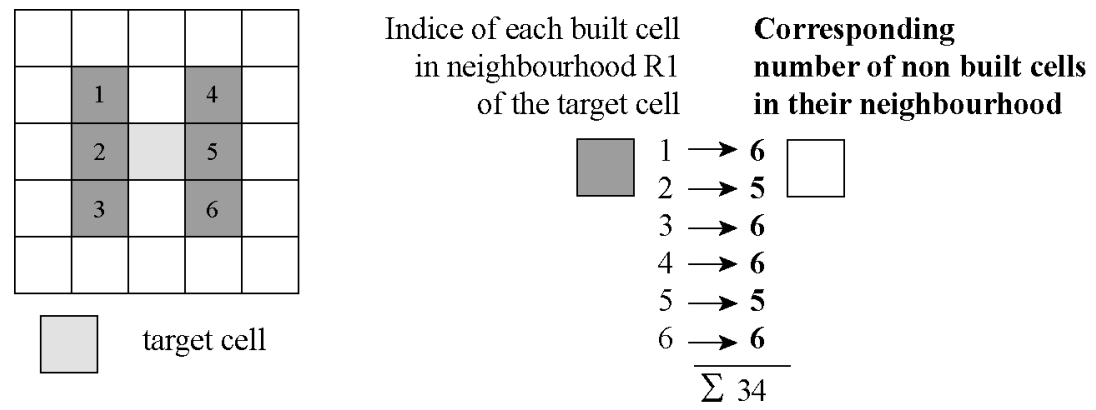
Concretely, rule 1 consists in counting, for each built cell in the immediate vicinity of the target cell, the number of non built cells directly adjacent to it. The sum of these numbers gives the rule's input value. A fuzzy membership function $\mu(x)$ describes the variable in the form of a degree of membership of a 'good evaluation’ fuzzy set.

$$
\mu(x)=x / 34 \text { with } \mu(x) \in[0 ; 1]
$$

$x$ being the sum of the number of non built cells adjacent to each built cell directly adjacent to the target cell

\section{Rules 2 and 3}

Two types of shops and services are distinguished according to how often people potentially use them: shops and services that are used daily, which are taken to include butchers, bakers, schools, newsagents and super- or hypermarkets; shops and services that are used weekly, (car repairs, hypermarkets-supermarkets, doctors, mini-markets, pharmacists, post-offices, cafés). Businesses are taken as forming commercial clusters. A commercial cluster is composed either of one isolated business, or of at least two businesses less than $200 \mathrm{~m}$ apart. A cluster may be characterized by both its daily and weekly frequentation.

Access from a cell to a commercial cluster is defined as the combination of the attractiveness of that cluster and its distance from the cell: a short distance increases accessibility to a cluster; a long distance reduces accessibility. Distances taken into account range from 0 (evaluation value equal to 1 ) to $600 \mathrm{~m}$ (evaluation value equal to 0 ). The attractiveness of a cluster varies with the number of businesses it contains and their diversity. Accessibility from the cell to the full range of shops and services is evaluated by allowing for all the commercial clusters present, and not just one. The principles behind this evaluation are: it is better to have a single highly accessible cluster than two moderately accessible clusters; where accessibility is equivalent, it is better to have two clusters 
rather than just one; a single very accessible cluster is practically as beneficial as a very accessible cluster plus a cluster to which there is very poor access.

Formally, rules 2 and 3 are defined as follows. Take:

- a set of cells: $i=(1,2 \ldots k)$

- a set of clusters of shops and services: $j=(1,2 \ldots l)$

- the number of shops and services in a cluster $j: n_{j}$

- the diversity of the businesses (number of different types of businesses) in a cluster $\mathrm{j}$ : $\delta_{j}$

- the distance (measured over the network) between a cell $i$ and a cluster $j: d_{i j}$

- accessibility from a cell $i$ to a cluster $j: Y_{i j}$

$$
Y_{i j}=\left[\mu\left(n_{j}\right)^{\mu\left(\delta_{j}\right)} \mu\left(d_{i j}\right)\right]^{1-\mu\left(d_{i j}\right)} \cdot\left[1-\left(1-\mu\left(n_{j}\right)^{\mu\left(\delta_{j}\right)}\right)\left(1-\mu\left(d_{i j}\right)\right)\right]^{\mu\left(d_{i j}\right)}
$$

$\varphi_{\mathrm{i}}$ is the evaluation of access from a cell to the set of clusters of shops and services visited daily.

$$
\phi_{i}=1-\prod\left(1-Y_{i j}\right)
$$

Equations 5 and 6 for calculating the values of $Y_{i j}$ and $\varphi_{i}$ involve applying Zimmermann's aggregation operator (Zimmermann and Zysno, 1983). The definition of functions $\mu\left(n_{j}\right), \mu\left(\delta_{j}\right)$ and $\mu\left(d_{i j}\right)$ for shops and services used daily and weekly is given in Appendix 1.

\section{Rule 4}

The objective of this rule is to limit the consumption of space by minimizing the construction of new stretches of road. The evaluation varies with the size of the cell (Figure 3). 
Figure 3. Formalization of the rule of proximity to the existing road network

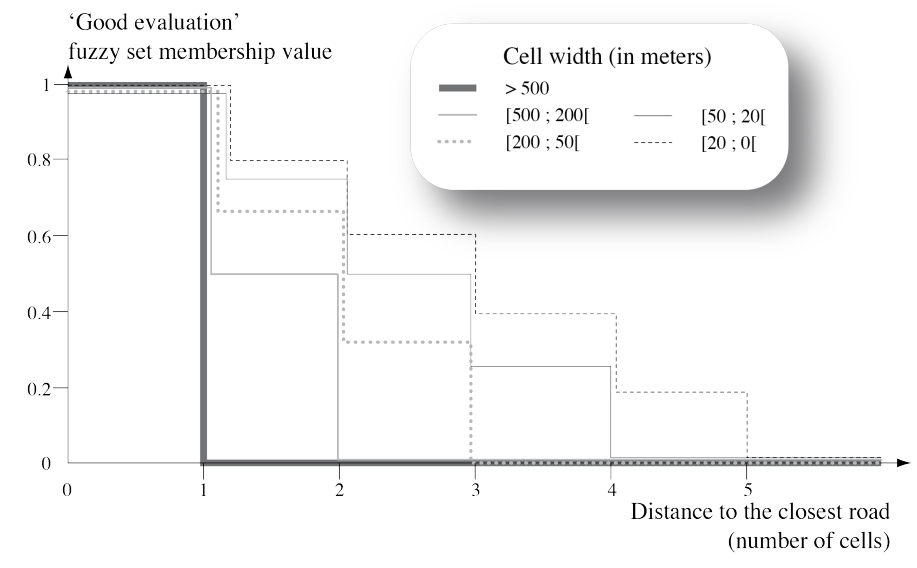

\subsection{Non developable zones}

Allowance for non developable zones is part of the multi-scale logic of MUP-City. If a grid square contains a higher proportion of non developable area than of urbanizable areas, then the grid square cannot be urbanized. Conversely, if a grid square contains a smaller proportion of non developable areas than of urbanizable areas, then the grid square may be urbanized. In this case, non developable areas will prevent urbanization when smaller grid squares come to be considered.

\section{Is access to various amenities better in fractal or non fractal urban patterns?}

To answer this question, three series of fractal and non fractal urbanization scenarios were created and compared in terms of their accessibility to various amenities.

Figure 4. The study area and its immediate environment; northern sector of the agglomeration of Besançon (France) 


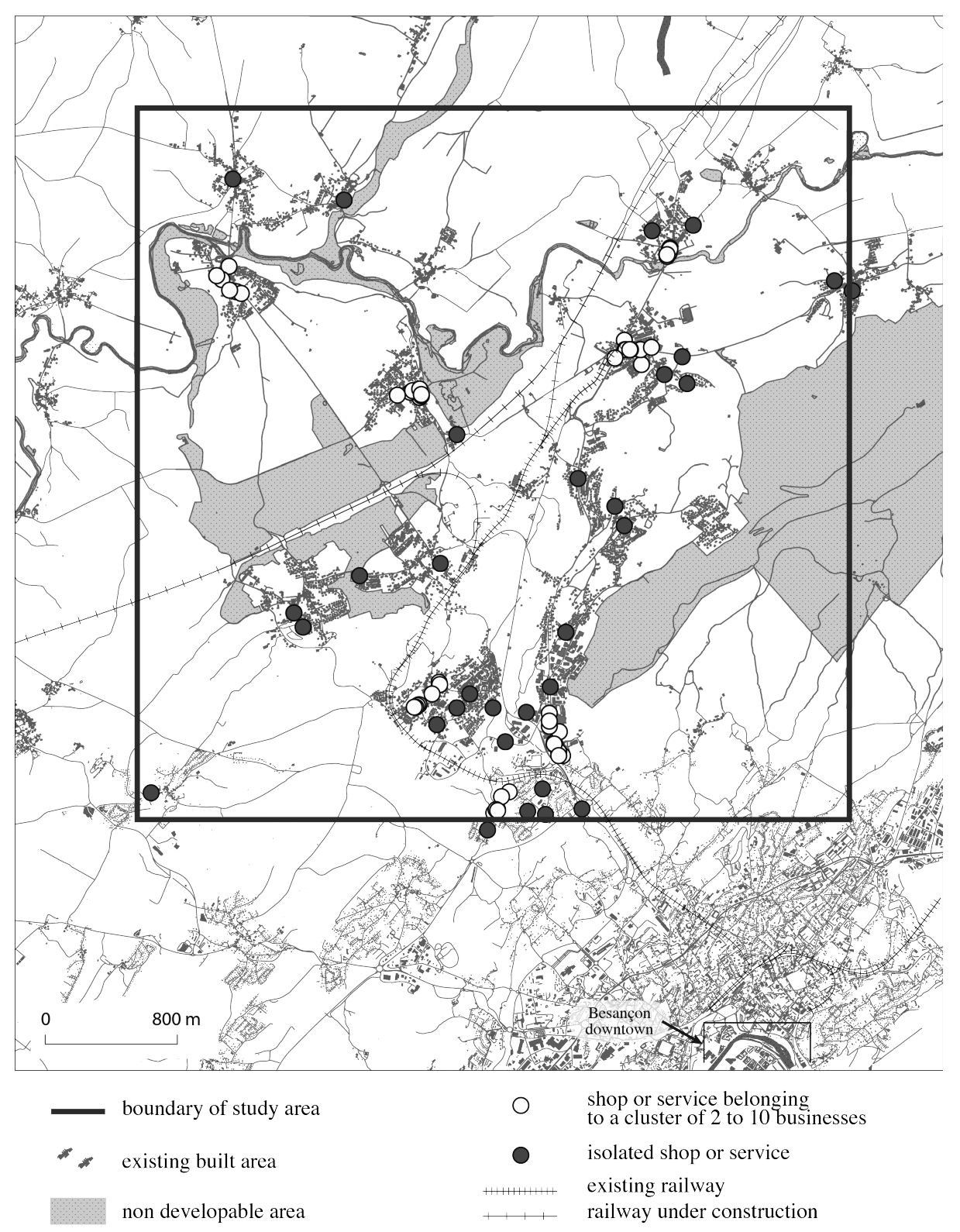

\subsection{Study area}

The study zone is a suburban sector of 14,000 inhabitants located to the north of the agglomeration of Besançon in eastern France (Figure 4). Shops and services that are potentially visited weekly outnumber those that are potentially used daily (63 to 32); the businesses are spatially scattered (some 30 isolated businesses versus 10 clusters of 2 to 10 businesses). For analysing the fractality of the built pattern, we estimated its correlation dimension (v) (Grassberger and Procaccia 1983) using Fractalyse 2.4 software (Vuidel et al, 2006). The estimated correlation dimension is 1.5. The built 
pattern seems to be clearly fractal only for inter-building distances of $45 \mathrm{~m}$ to $545 \mathrm{~m}$. Outside of this range of distances, the fit between the empirical curve representing the mean number of buildings present at a certain distance (correlation radius) and a power law is not good. We also estimate the self-similarity dimension $\left(D_{s}\right)$ of the built pattern. For this, we started from the fractal decomposition of the pattern (Table 2), and we calculated the geometric mean of the series of $N_{o b s}$ which gave the value 4.8. Then we estimated the fractal dimension considering a reduction factor $r$ of 3 by applying the formula:

$$
D_{s}=-\frac{\log \left(N_{o b s}\right)}{\log (1 / r)}
$$

The estimated $D_{s}$ is 1.43 , which is slightly different from the correlation dimension ( $\left.v\right)$ given above. In view of these two fractal dimensions, the urban development scenarios should consider an $N_{\max }$ value of 5 or more. However, we may also test urbanization scenarios corresponding to lower fractal dimensions ( $N_{\max }$ of 3 or 4 ) so as to develop the sectors of the study area characterized by low fractal dimensions or to accentuate the fractality of the built pattern for distance ranges that do not currently fit in with a fractal logic.

Table 2. Results of fractal decomposition of the initial built pattern

\begin{tabular}{|c|c|c|c|}
\hline Decomposition step & Grid square size $(\mathrm{m})$ & Cell size $(\mathrm{m})$ & Average $N_{\text {obs }}$ in grid square containing built land \\
\hline $\mathrm{l}_{1}$ & 1620 & 540 & 5.7 \\
\hline $\mathrm{l}_{2}$ & 540 & 180 & 4.6 \\
\hline $\mathrm{l}_{3}$ & 180 & 60 & 4.7 \\
\hline $\mathrm{l}_{4}$ & 60 & 20 & 4.4 \\
\hline
\end{tabular}




\subsection{A first series of 30 fractal and non fractal residential development scenarios}

We created 30 residential development scenarios for the study zone using MUP-City. The four accessibility rules were activated each time. Cell size at the final step of fractal decomposition was $20 \mathrm{~m}$. All the scenarios covered a square study area of the same size $(9,900 \mathrm{~m}$ sides) surrounded by a 3,000 m wide strip so as to take account of the characteristics of the neighbouring spaces and so avoid boundary artefacts in the calculations (Figure 4). Depending on the scenarios, the position of the study area (and so of the multi-scale decomposition grid) varied slightly. For the first ten scenarios, the study area was positioned as in Figure 4 (position G1). For the next ten scenarios, the study area was shifted $150 \mathrm{~m}$ to the west (position G2). For the last ten scenarios, the G1 study area was shifted 100 m north and 50 m east (position G3).

Fifteen of the 30 urbanization scenarios were fractal. The $N_{\max }$ value was 3, 4, 5, 6 or 7 . The other fifteen scenarios were called "non fractal" because the fractal rule of urbanization and the multiscale modelling were not applied to create them. For the non fractal scenarios, only the four rules of accessibility were applied and this was done on a grid of cells with sides $20 \mathrm{~m}$ long. The number of cells worth urbanizing was set as a priori the number of cells worth urbanizing identified by MUPCity for each corresponding fractal scenarios. By visually comparing and contrasting the scenarios, the forms of urban development can be seen to be very different (Figure 5). The non fractal scenarios are characterized by both compact (infilling developments) and axial forms that are found for example in Belgium (Thomas et al, 2008) and in Italy (Camagni et al, 2002). Fractal scenarios display more dispersed forms of development although remaining quite close to existing built cores. Newly urbanized cells are also located in the central fabric of villages. Contact between built and non built zones is fuzzier.

Figure 5. Examples of fractal and non fractal scenarios. (a) and (c) $\mathrm{N}_{\max }$ is equal to 4; (b) and (d) $\mathrm{N}_{\max }$ is equal to 6 

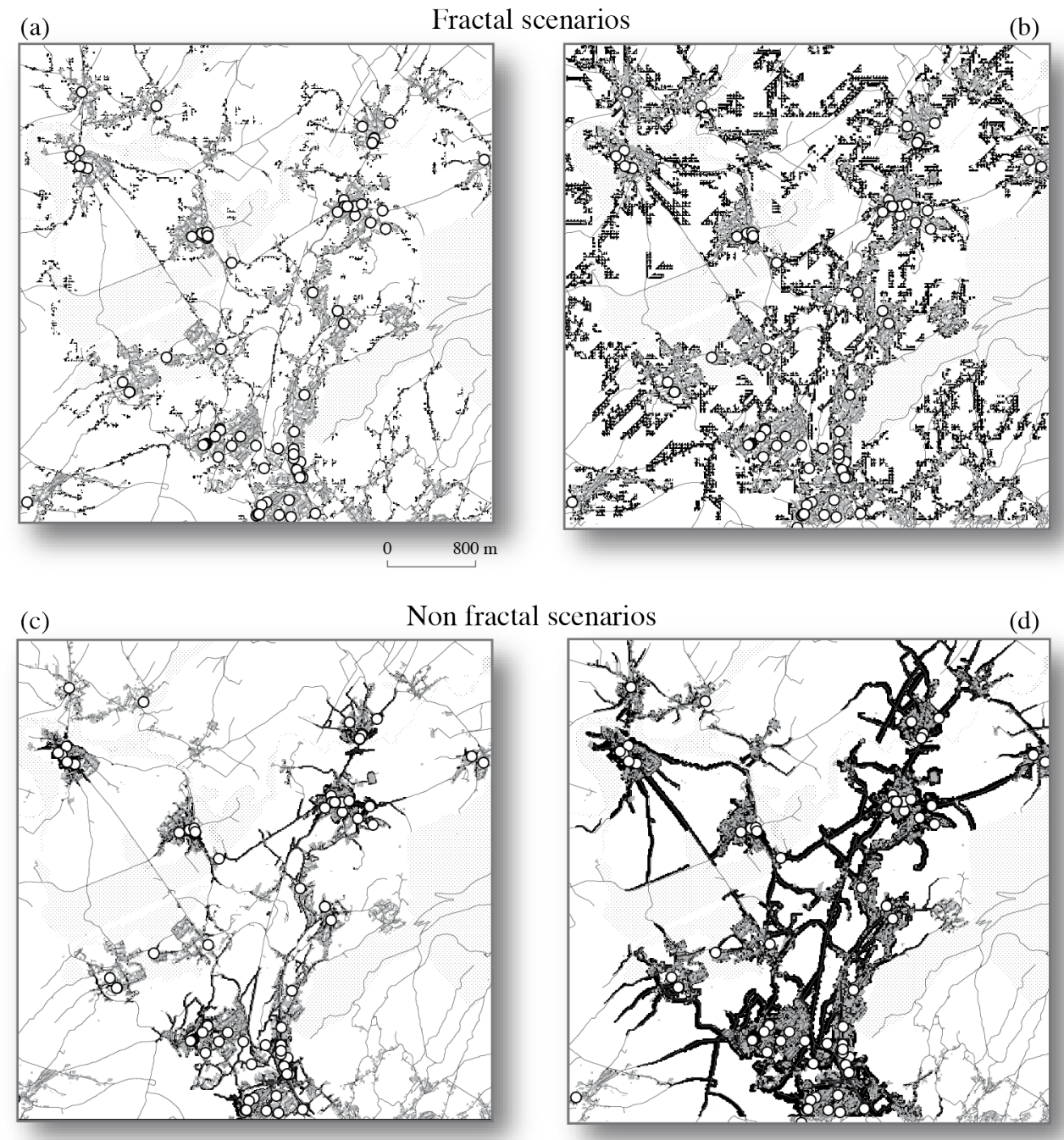

cell initially built-up

cell worth urbanizing according to the scenario

○ shop or service

\subsection{Ex-post assessment of accessibility}

Accessibility to shops and services and to open spaces was evaluated for each scenario. Eight evaluation criteria were used.

- $\quad$ the average distance from each built cell to the closest shop and service visited daily

- $\quad$ the average number of shops and services used daily within $400 \mathrm{~m}$ (walking distance) of each built cell

- $\quad$ the average distance from each built cell to the closest shop and service visited weekly

- $\quad$ the average number of shops and services used weekly within 2,000 m (cycling distance) of each built cell

- the proportion of built cells adjacent to at least one non built cell 
- $\quad$ the average number of non built cells adjacent to each built cell

- the average distance from each built cell to the urbanized border

- the proportion of built cells located within $5 \mathrm{~m}$ of the urbanized border

The average distance to a given set of amenities indicates the proximity of the residents to those amenities. The average number of amenities at a given distance indicates the supply of amenities in the neighbourhood (Apparicio et al., 2006). All of the distances were calculated over the road network. We worked on the road network alone to calculate distances to shops and services used weekly; we worked on the road network plus paths and tracks to compute distances to shops and services used daily as well as distances to the urbanized border.

The urbanized border was defined as being the boundary of the morphological agglomeration identified by the method described in Tannier et al, 2011. By applying this method to the current metropolitan area of Besançon, we identified a threshold distance of $276 \mathrm{~m}$ at which distances between buildings no longer exhibit the same fractal behaviour. Mapping the urbanized border then consists in applying a positive buffer followed by a negative buffer to the map of the built area with the buffer diameter being equal to $276 \mathrm{~m}$. When creating residential development scenarios, the urbanization of new cells may modify the value of this distance threshold. However, it would have been very time-consuming to re-compute a threshold distance for each of the scenarios. Besides, the study area covers only 13 of the 234 municipalities that make up the Besançon metropolitan area. We therefore opted to apply the same $276 \mathrm{~m}$ threshold to map the urbanized border in all the scenarios.

The results in Table 3 show that access to shops and services is invariably better for the non fractal scenarios than for the fractal scenarios. This is visible both for the crude values of indicators and for the change between the initial situation and the simulated situation. Depending on the indicators, a 
negative rate of change may mean better access under the simulated scenario compared with the initial situation (e.g. shorter distance to the nearest shop) or poorer access under the simulated scenario than in the initial situation (e.g. fewer shops within $400 \mathrm{~m}$ of each residential cell). The non fractal scenarios improve access to shops and services used daily with respect to the current situation when $N_{\max }$ is 3 or 4 (weak to moderate residential development). They also improve access to shops and services used weekly, except when $N_{\max }$ is 7 (intense residential development). On the contrary, fractal scenarios never improve access to shops and services compared with the initial situation. The greater $N_{\max }$, the worse the access to shops and services under fractal scenarios compared with the initial situation. This observation is reversed when we consider access to open spaces. Fractal scenarios maintain the initial level of access to open spaces, or even improve it. For non fractal scenarios, such access declines as $N_{\max }$ increases.

The results obtained scarcely vary regardless of the position G1, G2 or G3 of the study area. So the model does not seem especially sensitive to the position of the fractal decomposition grid. However, the built pattern generated does differ markedly for the three grid positions (Figure 6). And so, for a given built pattern, there are a host of possible choices of cells that lend themselves to potential urbanization while complying with the model’s urbanization rules.

Figure 6. Excerpt from a fractal scenario $\mathrm{N}_{\max }=5$. (a) study area in position G1; (b) study area in position G2.
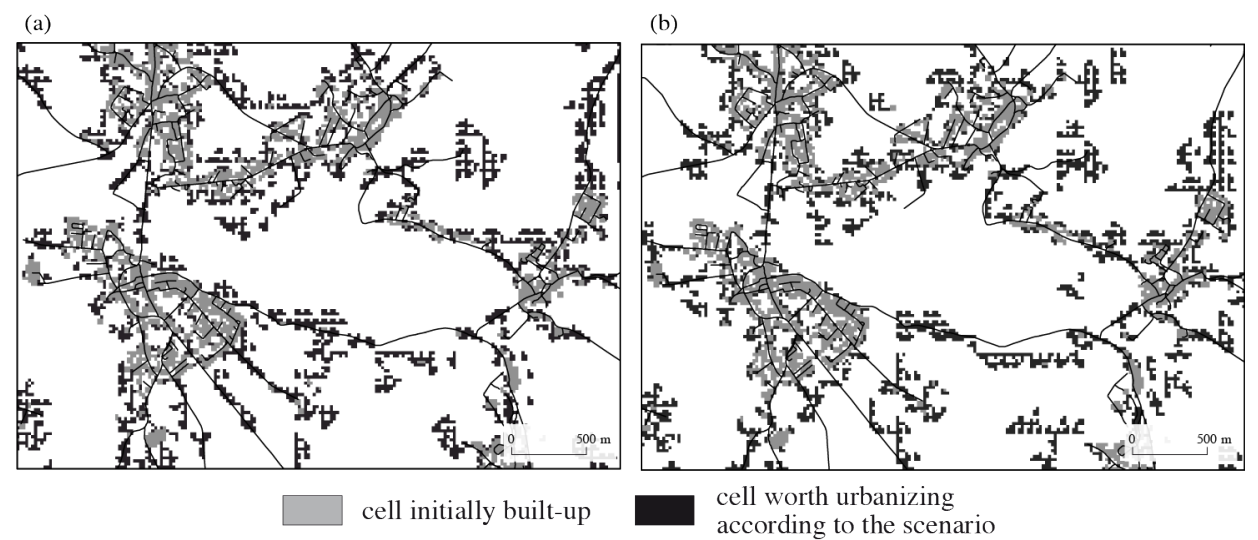
Table 3. Accessibility to shops and services and to open spaces for the first $\mathbf{3 0}$ scenarios

(a) Initial spatial configuration (current situation)

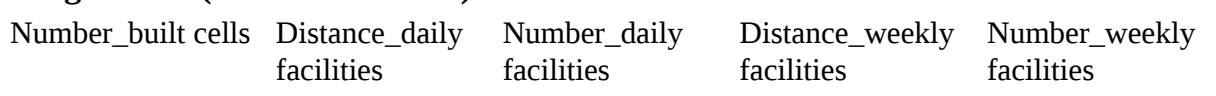

0.49

998

6.8

\%built cells contiguous Mean number_non built cell neighbourhood

Distance_outside \% built cells_ city urban boundary

$$
16624
$$

Number_daily facilities

Distance_weekly Number_weekly or not (NF) facilities

$\begin{array}{lr}20744 & 838 \\ 20744 & 1060 \\ 27000 & 863 \\ 27000 & 1179 \\ 37828 & 956 \\ 37828 & 1336 \\ 55642 & 1070 \\ 55642 & 1499 \\ 82228 & 1221 \\ 82228 & 1622\end{array}$

0.65
0.42
0.55
0.35
0.42
0.27
0.31
0.21
0.22
0.16
facilities

865
1118
819
1249
847
1416
928
1607
1112
1723

\%built cells contiguous built cell

Mean number_non built cells in neighbourhood

74.20
90.27
68.67
91.91
56.69
93.23
36.33
92.09
23.76
88.63

(c) Study area position G1: rate of change compared with current situation. Bold print: improvement in access compared with initial situation.

$\mathrm{N}_{\max } \quad$ Fractal (F) Number_built cells Distance daily Number_daily Distance_weekly Number_weekly or not (NF) facilities facilities facilities facilities \%built cells built cell on Mean number_non NF F

NF

F

NF

NF

0.25
0.25
0.62
0.62
1.28
1.28
2.35
2.35
3.95

$\mathbf{- 0 . 1 2}$
0.11
$\mathbf{- 0 . 1 0}$
0.23
$\mathbf{0 . 0 0}$
0.40
0.12
0.57
0.28

$\mathbf{- 0 . 1 3}$
0.12
$\mathbf{- 0 . 1 8}$
0.25
$\mathbf{- 0 . 1 5}$
0.42
$\mathbf{- 0 . 0 7}$
0.61
0.11

$\mathbf{0 . 1 6}$
-0.06
$\mathbf{0 . 2 5}$
-0.12
$\mathbf{0 . 1 9}$
-0.19
$\mathbf{0 . 0 9}$
-0.26
-0.04

2.8

Distance_outside \% built cells_ city

$\begin{array}{ll}298 * & 13.27 \\ 298 * & 18.41 \\ 379 * & 14.13 \\ 327 * & 19.30 \\ 502 * & 16.17 \\ 365 * & 19.75 \\ 591 * & 13.82 \\ 453 * & 20.46 \\ 661 * & 11.64 \\ 607 * & 19.66\end{array}$

15.27 city neighbourhood

$\begin{array}{rr}-0.16 & -0.25 \\ \mathbf{0 . 0 2} & \mathbf{0 . 1 1} \\ -0.22 & -0.39 \\ \mathbf{0 . 0 4} & \mathbf{0 . 1 4} \\ -0.36 & -0.54 \\ \mathbf{0 . 0 5} & \mathbf{0 . 0 7} \\ -0.59 & -0.71 \\ \mathbf{0 . 0 4} & -0.07 \\ -0.73 & -0.82\end{array}$

$\%$ built cells urban boundary

$\begin{array}{rr}0.20 & -0.13 \\ 0.20 & \mathbf{0 . 2 1} \\ 0.53 & -0.07 \\ 0.32 & \mathbf{0 . 2 6} \\ 1.02 & \mathbf{0 . 0 6} \\ 0.47 & \mathbf{0 . 2 9} \\ 1.38 & -0.10 \\ 0.83 & \mathbf{0 . 3 4} \\ 1.67 & -0.24\end{array}$


$\mathrm{N}_{\max } \quad$ Fractal (F) Number_built cells Distance_daily Number_daily or not (NF) facilities
Distance_weekly Number_weekly facilities facilities \%built cells contiguous built cell
Mean number_non built cells in neighbourhood
Distance_outside \% built cells city urban boundary 
Table 4. Accessibility to shops and services and to open spaces for the second series of scenarios

Rate of change compared with current situation. Bold print: improvement in access compared with scenarios G2 of the first series (Table 3d).

$\mathrm{N}_{\max } \quad$ Fractal (F) Number_built cells Distance_daily Number_daily Distance_weekly Number_weekly \%built cells $\quad$ Mean number_non

facilities

facilities

facilities

facilities

built cell

built cells in

Distance outside \% built cells

city

urban boundary

$\begin{array}{ll}3 & \mathrm{NF} \\ 3 & \mathrm{~F} \\ 4 & \mathrm{NF} \\ 4 & \mathrm{~F} \\ 5 & \mathrm{NF} \\ 5 & \mathrm{~F} \\ 6 & \mathrm{NF} \\ 6 & \mathrm{~F} \\ 7 & \mathrm{NF} \\ 7 & \mathrm{~F}\end{array}$

$\begin{array}{rr}0.26 & \mathbf{- 0 . 3 8} \\ 0.26 & \mathbf{- 0 . 2 0} \\ 0.65 & \mathbf{- 0 . 3 5} \\ 0.65 & \mathbf{- 0 . 0 7} \\ 1.34 & \mathbf{- 0 . 2 4} \\ 1.34 & \mathbf{0 . 0 9} \\ 2.44 & \mathbf{- 0 . 1 4} \\ 2.44 & \mathbf{0 . 2 3} \\ 4.07 & \mathbf{0 . 0 2} \\ 4.07 & \mathbf{0 . 3 5}\end{array}$

0.63
-0.10
0.41
-0.08
0.10
-0.27
-0.18
-0.45
-0.41
-0.57

0.08
0.39
0.05
0.54
0.11
0.72
0.21
0.89
0.45
1.00

0.04

$-0.14$

0.13

$-0.20$

-0.19
0.02

$-0.29$

$-0.28$

0.10

$-0.43$

0.04

$-0.39$

0.05

$-0.60$

0.04

$\mathbf{- 0 . 7 2}$

0.00

$$
0.13
$$

$-0.56$

$$
\begin{aligned}
& -0.28 \\
& -0.01
\end{aligned}
$$$$
-0.33
$$$$
-0.16
$$$$
-0.39
$$

$$
\begin{array}{r}
0.07 \\
-0.72
\end{array}
$$$$
-0.07
$$$$
\begin{aligned}
& -0.07 \\
& -0.79
\end{aligned}
$$$$
0.35-0.57
$$

1.00

$-0.26$

Table 5. Accessibility to shops and services and to open spaces for the third series of scenarios

Rate of change compared with current situation. Bold print: improvement in access compared with initial situation.

$\mathrm{N}_{\max } \quad$ Fractal (F) Number_built cells Distance_daily Number_daily Distance_weekly Number_weekly \%built cells or not (NF)

facilities

facilities

facilities

facilities

contiguous built cell

$\begin{array}{rr}\mathbf{- 0 . 1 1} & \mathbf{0 . 1 2} \\ 0.07 & -0.04 \\ \mathbf{- 0 . 1 7} & \mathbf{0 . 2 2} \\ 0.14 & -0.07 \\ \mathbf{- 0 . 1 7} & \mathbf{0 . 2 2} \\ 0.22 & -0.12 \\ \mathbf{- 0 . 1 2} & \mathbf{0 . 1 6} \\ 0.33 & -0.18 \\ 0.01 & 0.01 \\ 0.44 & -0.22\end{array}$

$\begin{array}{ll}3 & \text { NF } \\ 3 & \text { F } \\ 4 & \text { NF } \\ 4 & \text { F } \\ 5 & \text { NF } \\ 5 & \text { F } \\ 6 & \text { NF } \\ 6 & \text { F } \\ 7 & \text { NF } \\ 7 & \text { F }\end{array}$

0.17
0.18
0.44
0.45
0.92
0.94
1.75
1.76
3.08
3.10

$\mathbf{- 0 . 1 0}$
0.06
$\mathbf{- 0 . 1 3}$
0.13
$\mathbf{- 0 . 0 5}$
0.22
0.05
0.33
0.19
0.45

$\mathbf{0 . 3 3}$
-0.10
$\mathbf{0 . 2 2}$
-0.20
-0.02
-0.35
-0.27
-0.49
-0.47
-0.59

Mean number_non

built cells in

neighbourhood
Distance_outside \% built cells_ city urban boundary

-0.13
$\mathbf{0 . 0 1}$
-0.22
$\mathbf{0 . 0 3}$
-0.27
$\mathbf{0 . 0 4}$
-0.48
$\mathbf{0 . 0 3}$
-0.68
-0.02

-0.20
$\mathbf{0 . 0 6}$
-0.37
$\mathbf{0 . 0 8}$
-0.44
$\mathbf{0 . 0 2}$
-0.62
-0.10
-0.76
-0.27

0.13
0.19
0.33
0.33
0.87
0.44
1.23
0.75
1.44
1.33

$-0.10$

0.11

$-0.14$

0.19

$-0.02$

0.23

$-0.07$

0.25

$-0.15$

0.13 


\subsection{A second series of 10 scenarios simulating a change in the commercial framework}

This second series of scenarios is designed to determine whether a more hierarchical commercial framework (following the logic of Christaller's central place theory) improves access in a fractal city more than in a compact city. The ten scenarios tested, five fractal and their non fractal counterparts, were identical to the ten scenarios of the previous series in position G2 apart from the spatial organization of shops and services. The total number of businesses was the same as in the first series of scenarios, but the number of businesses used daily was increased (43 businesses) while the number used weekly was reduced (54 businesses). The businesses were also re-located so as to form a smaller number of larger clusters (11 isolated businesses and 12 clusters of 2 to 15 businesses).

Comparison of the access indicators for initially built cells shows that the change in the spatial organization of shops and services clearly improves access to businesses used daily; access to businesses used weekly is poorer. Logically, the residential development scenarios simulated from the new spatial organization of shops and services also perform better in terms of access to shops and services used daily than the G2 scenarios of the first series (Table 4). We observe the reverse phenomenon for access to shops and services used weekly. This second series of scenarios shows also that the change in spatial organization of shops and services does not affect the differences in accessibility between each fractal scenario and its non fractal counterpart; it does not affect the differences in access to open spaces either.

\subsection{A third series of 10 scenarios to take into account the density of the local built environment}

By default the fractal rule for urbanization requires that all the grid squares where there is already at least one building be urbanized. In this way the model can identify cells worth urbanizing in zones that are practically empty, and often far from any shopping and service centre. To avoid this phenomenon, we introduced a density threshold below which a grid square was considered non 
built. In this way, at a decomposition step $i$, more grid squares are considered non built and cannot be urbanized at step $i+1$. We opted to work with a built density threshold of $1 \times 10^{-4}$. In this way, a grid square with sides $1620 \mathrm{~m}$ long is considered non built if it contains less than $262.44 \mathrm{~m}^{2}$ of built area (which is equivalent to two detached houses). Likewise, a grid square with sides $180 \mathrm{~m}$ long is considered non built if it contains less than $3.24 \mathrm{~m}^{2}$ of built area (i.e. a hut or a shed). When tested with a higher density threshold $\left(1 \times 10^{-3}\right)$ too many grid squares could be urbanized; with a lower density threshold $\left(1 \times 10^{-5}\right)$ too few grid squares became non urbanizable.

In the case of non fractal scenarios, allowance for built density comes down simply to considering that fewer cells are initially urbanized. In this way, simulated urbanization is less constrained by the pre-existing built forms.

Considering all the indicators computed, access to the amenities is slightly better for this third series of simulations (Table 5) than for the simulations of the first series in position G1 (Table 3c). However, each scenario of the third series contains fewer newly urbanized cells than the corresponding scenario of the first series. It is quite possible therefore that the improvement observed is not due to the density constraint but to less intense urbanization. The differences between fractal and non fractal scenarios are slightly less marked for this third series of scenarios than for the first series. So, the introduction of a density constraint reduces the difference between the fractal and non fractal scenarios.

\subsection{Summary of results}

The simulations show that, compared with non fractal urbanization scenarios, fractal scenarios involve travelling shorter distances to reach various types of open space, but greater distances to visit the various types of shops and services. This observation holds whatever the position of the 
study area, with or without the introduction of a built density threshold constraining residential development, and with or without modifying the spatial organization of shops and services. This suggests that access to amenities depends more on the urban form of reference (fractal or non fractal here) than on the built density or the location of shops and services.

\section{Conclusion}

This paper set out to answer two questions: is it possible to take better account of urban form and its implications in terms of urban operation at various scales in an SDSS or a PSS? Does the fractal city model provide a worthwhile alternative to classic urban models of the compact or 'wisely compact' city? In answer to the first question, we have proposed the MUP-City simulation system based on multi-scale spatial modelling obeying a fractal principle. MUP-City integrates the two essential components of urban spatial dynamics: forms (through multi-scale decomposition and the fractal rule for urbanization) and processes (through the four accessibility rules). By using MUPCity, we have explored a few avenues for creating and evaluating future urbanization forms allowing more sustainable suburban trips: walking instead of driving, purchasing convenience goods from stores near home instead of purchasing in big retail centres far from home or work, visiting neighbouring open spaces. These explorations have shown that access to amenities varies more with the built pattern (fractal or non fractal) than with the location of shops and services. We can, however, improve access to shops and services in fractal scenarios by altering the location of shops and services, whereas we cannot improve access to open spaces in non fractal scenarios without changing the built form of reference. Thus a fractal urbanization policy combined with planned commercial development could allow good local access both to open spaces and to shops and services. 
For this first application of MUP-city software, we have considered purely spatial accessibility, measured in terms of distance to travel. The challenge now is to determine whether fractal scenarios provide a better compromise than non fractal scenarios, in other words, to determine whether or not the positive differential of accessibility in favour of fractal scenarios with regard to open spaces overcompensates the negative differential of accessibility with regard to shops and services. This presupposes taking account of individual behaviour, and measuring activity-based or utility-based accessibility, allowing for how often each amenity is used and for the other factors in the choice of places visited (time constraints, activity chains, quality of facilities, and so on) (Neutens et al, 2010).

The results obtained are an incentive to test the MUP-City application on other study areas so as to confirm or invalidate the results and to highlight their variability or their stability. It would also be worth going beyond local access to shops and services and working on the scale of an agglomeration, taking into account access to city-centre amenities. This approach seems particularly worth exploring since one of the possible causes of the relative failure of New Urbanism in terms of improving the sustainability of travel (especially reducing the mileage done by private motor vehicles) is that the solutions proposed are not part of a local urban development. Might fractal urbanization on the scale of an agglomeration allow better results to be achieved?

\section{Acknowledgements}

This research was financed by France's ministry for sustainable development, ecology and regional planning as part of the PREDIT 3 program.

\section{References}

Apparicio P, Séguin A-M, 2006, "Measuring the accessibility of services and facilities for residents of public housing in Montreal" Urban Studies 43(1) 187-211 
Arlinghaus S L, Nystuen J D, 1990, "Geometry of boundary exchanges" Geographical Review 80(1) 21-31

Batty M, Kim K, 1992, "Form follows function: reformulating urban population density function" Urban Studies 29(7) 1043-1070

Batty M, Longley P, 1986, "The fractal simulation of urban structure" Environment and Planning A 18 pp $1143-1179$

Batty M, Xie Y, 1996, "Preliminary evidence for a theory of the fractal city" Environment and Planning A 28 pp $1745-$ 1762

Benguigui L, Blumenfeld E, Czamanski D, 2006, "The dynamics of the Tel Aviv morphology" Environment and Planning B 33 269-284

Benguigui L, Czamanski D, 2004, "Simulation analysis of the fractality of cities" Geographical Analysis 36(1) 69-84

Benguigui L, Czamanski D, Marinov M, Portugali Y, 2000 "When and where is a city fractal?", Environment and Planning B 27(4) 507-519

Breheny M J, 1997, "Urban compaction: feasible and acceptable?" Cities 14 209-217

Burton E, 2000, "The compact city: just or just compact?" Urban Studies 37(11) 1969-2001

Calthorpe P, 1993 The next American metropolis: ecology, community, and the American dream (Princeton Architectural Press, New York)

Camagni R, Gibelli M, Rigamonti P, 2002, "Urban mobility and urban form: the social and environmental costs of different patterns of urban expansion" Ecological Economics 40 199- 216

Cavailhès J, Frankhauser P, Peeters D, Thomas I, 2004, "Where Alonso meets Sierpinski: an urban economic model of fractal metropolitan area" Environment and Planning A 36 1471-1498

Cervero R, Murakami J, 2010, "Effects of built environment on vehicle miles traveled: evidence from 370 us urbanized areas" Environment and planning A 42 400-418

Chen Y, 2009, "A new model of urban population density indicating latent fractal structure" International Journal of urban sustainable development 1(1-2) 89-110

Conway T, 2009, "Local environmental impacts of alternative forms of residential development" Environment and Planning B: Planning and Design 36(5) 927-943

Dantzig G, Saaty T, 1973 Compact city: a plan for a liveable urban environment (Freeman, San Francisco)

Frankhauser P, 1988, "Fractal aspects of urban systems" Sonderforschungsbereich 230 "Natürliche Konstruktionen" $67-76$ 
Frankhauser P, 2000, "La fragmentation des espaces urbains et périurbains : une approche fractale" in Structure des villes, entreprises et marchés urbains Ed P H Derycke (L'Harmattan, Paris) pp 25-50

Frankhauser P, 2004, "Comparing the morphology of urban patterns in Europe: a fractal approach" in European cities insights on outskirts Eds A Borsdorf, P Zembri (Brussels) pp 79-105

Frankhauser P, Genre-Grandpierre C, 1998, "La géométrie fractale: un nouvel outil pour évaluer le rôle de la morphologie des réseaux de transport public dans l'organisation spatiale des agglomérations" Les cahiers scientifiques du transport (33) 41-78

Geurs K T, van Wee B, 2006, "Ex-post evaluation of thirty years of compact urban development in the Netherlands" Urban studies 43(1) 139-160

Geurs K, Zondag B, de Jong G, de Bok M, 2010, "Accessibility appraisal of land-use/transport policy strategies: more than just adding up travel-time savings" Transportation Research Part D 15 382-393

Gouyet J, 1992, Physique et structures fractales (Masson, Paris)

Grassberger P, Procaccia I, 1983, "Measuring the strangeness of strange attractors" Physica D 9 189-208

Janssen R, van Herwijnen M, Stewart T, Aerts J, 2008, "Multiobjective decision support for land-use planning" Environment and Planning B: Planning and Design 35 740-756

Klosterman R, 1999, "The what if? collaborative planning support system" Environment and planning B: Planning and design 26 393-408

Li X, Liu X, 2008, "Embedding sustainable development strategies in agent-based models for use as a planning tool" International Journal of Geographical Information Science 22(1) 21 - 45

Ligmann-Zielinska A, Church R L, Jankowski P, 2008, "Spatial optimization as a generative technique for sustainable multiobjective land-use allocation" International Journal of Geographical Information Science 22(6) 601-622

Longley P, Batty M, 1989, "On the fractal measurement of geographical boundaries" Geographical Analysis 21(1) 4767

Malczewski J, 2004, "GIS-based land-use suitability analysis: a critical overview" Progress in Planning 62 3-65

Mandelbrot B, 1982 The fractal geometry of nature (Freeman, San Francisco)

Neutens T, Schwanen T, Witlox F, De Maeyer P, 2010, "Equity of urban service delivery: a comparison of different accessibility measures" Environment and Planning A 42 1613-1635

Newman P W G, Kenworthy J R, 1989 Cities and automobile dependence (Gower Publishing) 
Oh K, Jeong, Y, 2002, "The usefulness of the GIS-fuzzy set approach in evaluating the urban residential environment" Environment and Planning B: Planning and Design 29 589-606

Saarlos D, Arentze T, Borgers A, Timmermans H, 2005, "A multiagent model for alternative plan generation" Environment and Planning B: Planning and Design 32 505-522

Schwanen T, Dieleman F M, Dijst M, 2001, "Travel behaviour in Dutch monocentric and polycentric urban systems" Journal of transport geography (9) 173-186

Shen G, 2002, "Fractal dimension and fractal growth of urbanized areas" International Journal of Geographical Information Science 16(5) 437-519

Stamps A E, 2002, "Fractals, skylines, nature and beauty" Landscape and urban planning 60(3) 163-184

Tannier C, Thomas I, Vuidel G, Frankhauser P, 2011, "A fractal approach to identifying urban boundaries" Geographical Analysis 43 211-226

Tannier C, Vuidel G, Frankhauser P, Houot H, 2010, "Simulation fractale d'urbanisation - MUP-city, un modèle multiéchelle pour localiser de nouvelles implantations résidentielles" Revue internationale de géomatique 20(3) 303-329

Thomas I, Frankhauser P, De Keersmaecker M, 2007, "Fractal dimension versus density of the built-up surfaces in the periphery of Brussels" Papers in Regional Science 86(2) 287-307

Thomas I, Frankhauser P, Biernacki C, 2008, "The morphology of built-up landscapes in Wallonia (Belgium): a classification using fractal indices" Landscape and Urban Planning 84 99-115

Vuidel G, Frankhauser P, Tannier C, 2006, "Fractalyse 2.4" free software downloadable at: http://www.fractalyse.org/ White R, Engelen G, 1993, "Cellular automata and fractal urban form: a cellular modelling approach to the evolution of urban land-use patterns" Environment and Planning A 25(8) 1175-1199

Yager R R, 1978, "Fuzzy decision making including unequal objectives" Fuzzy sets and systems 1 87-95

Zadeh L A, 1965, "Fuzzy sets" Information and Control 8(3) 338-353

Zimmermann H, 1987 Fuzzy sets, decision making and expert systems (Kluwer Academic Publishers, Boston [u.a.])

Zimmermann H J, Zysno P, 1983, "Decisions and evaluations by hierarchical aggregation of information" Fuzzy sets and systems 10 243-260 
Appendix 1. Definition of functions $\mu\left(n_{j}\right), \mu\left(\delta_{j}\right)$ and $\mu\left(d_{i j}\right)$ for commercial clusters used daily and weekly

\section{Commercial cluster used daily}

Assessment of the number of

businesses in a commercial

cluster

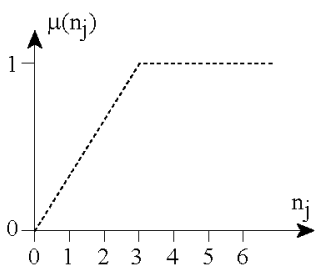

\section{Commercial cluster used weekly}

Assessment of the number of businesses in a commercial cluster

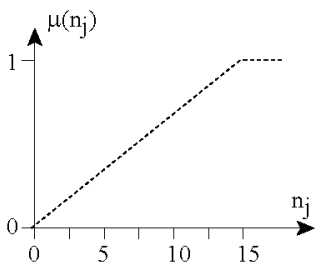

Assessement of the diversity of types of businesses in a commercial cluster

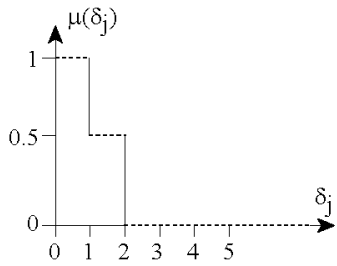

Assessement of the diversity of types of businesses in a commercial cluster

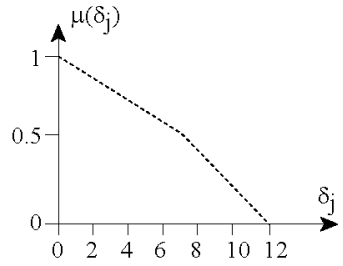

Assessment of the distance

between a residential cell

and a commercial cluster

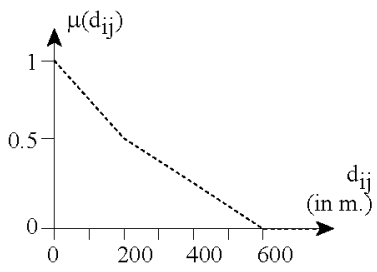

Assessment of the distance between a residential cell and a commercial cluster

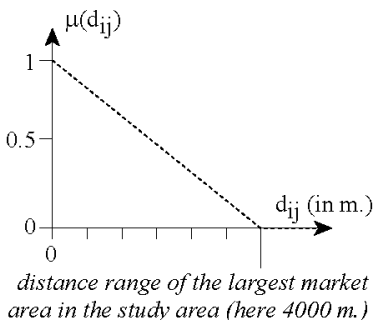

Taken from Tannier et al., 2010 